\title{
Synthesis of a Nanostructured Composite: Octakis(1-propyl-1H-1,2,3-triazole-4-yl(methyl 2-chlorobenzoate))octasilsesquioxane via Click Reaction
}

\author{
Ghodsi Mohammadi Ziarani, ${ }^{1, *}$ Monireh Shakiba Nahad, ${ }^{1}$ \\ Negar Lashgari ${ }^{2}$ and Alireza Badiei ${ }^{2}$ \\ ${ }^{1}$ Department of Chemistry, Alzahra University, PO Box 1993893973, Tehran, Iran \\ ${ }^{2}$ School of Chemistry, College of Science, University of Tehran, PO Box 14155-6455, Tehran, Iran \\ *Corresponding author: E-mail: gmziarani@hotmail.com,gmohammadi@alzahra.ac.ir \\ Tel-fax: +982188041344
}

Received: 04-09-2014

\begin{abstract}
Octakis(1-propyl-1H-1,2,3-triazole-4-yl(methyl 2-chlorobenzoate))octasilsesquioxanes as functionalized silsesquioxanes were synthesized via click reaction (copper-catalyzed Huisgen 1,3-dipolar cycloaddition reaction) between azidemoiety functionalized silsesquioxane and prop-2-ynyl 2-chlorobenzoate. The latter one was synthesized via the condensation reaction of propargyl alcohol and 2-chlorobenzoyl chloride in the presence of SBA-Pr- $\mathrm{NH}_{2}\left(\mathrm{Santa}_{\mathrm{Barbara}}\right.$ Amorphous type material) as a nano basic catalyst. This approach provides a simple and convenient route to efficiently functionalize a wide range of new structures on the surface of silsesquioxanes.
\end{abstract}

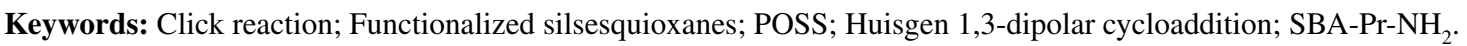

\section{Introduction}

Organic-inorganic hybrid nanomaterials with well-defined architectures have recently attracted a great deal of attention because of their remarkable performances as materials with controlled morphology at nanometer scale. ${ }^{1,2}$ In the past years, polyhedral oligomeric silsesquioxanes (POSS) continue to be of interest for further functionalization with reactive groups to develop nano-hybrid materials. ${ }^{3-7}$ They have been widely utilized to produce hybrid materials with improved properties such as enhanced thermomechanical properties ${ }^{8,9}$ good thermal stability ${ }^{10}$ atom oxygen resistance, ${ }^{11}$ abrasion resistance, ${ }^{12}$ and low water uptake. ${ }^{13}$

POSS with rigid cage-like structures are a class of important nano-sized molecules consisting of an inorganic Si-O-Si core. A typical POSS molecule possesses a cubic rigid $\left(\mathrm{T}_{8}\right)$ structure represented by the formula $\mathrm{R}_{8} \mathrm{Si}_{8} \mathrm{O}_{12}$, where the central inorganic core $\left(\mathrm{Si}_{8} \mathrm{O}_{12}\right)$ is functionalized with organic moieties $(\mathrm{R})$ at each of the eight vertices. ${ }^{14,15}$
Organic groups are introduced into the molecule either directly, during the synthesis or by a transformation of existing groups. ${ }^{16}$ Over the last years, researchers have made a library of functionalized POSS compounds such as octaphenols, ${ }^{17}$ octaisocyanates, ${ }^{18}$ oligoethylene oxides, ${ }^{19}$ and liquid crystalline materials. ${ }^{20}$

The copper-catalyzed Huisgen azide-alkyne cycloaddition reaction (click chemistry CuAAC) as an entry point to 1,4-substituted triazoles is a versatile tool, now widely used for conjugation of a variety of molecules. ${ }^{21,22}$ To date several synthetic routes to click functionalized silsesquioxanes have been reported for azido substituted POSS. ${ }^{23-26}$

This paper deals first with the synthesis of octakis(1-propyl-1H-1,2,3-triazole-4-yl(methyl 2-chlorobenzoate))POSS scaffold $\mathbf{5}$ by copper catalyzed click cycloaddition reaction as a useful approach for the synthesis of functionalized silsesquioxane. Also, in our continued interest towards the application of nano-porous heterogeneous solid catalysts to the synthesis of heterocyclic 
compounds, ${ }^{27-29}$ we have decided to use $\mathrm{SBA}-\mathrm{Pr}-\mathrm{NH}_{2}$ as a heterogeneous solid basic catalyst in the synthesis of prop-2-ynyl 2-chlorobenzoate. SBA-15 is a kind of mesoporous silica featuring a well-ordered hexagonal structure, large pore size, high surface area, and high thermal stability that can conveniently include functional groups into its mesoporous framework to create efficient solid catalysts with improved catalytic properties as compared to conventional homogeneous and heterogeneous catalysts.

\section{Experimental}

\section{1. Materials and Instrumentations}

All chemicals were obtained commercially and used without further purification. Fourier transform-infrared (FT-IR) spectroscopic measurements were performed using a Bruker 500 scientific spectrometer as $\mathrm{KBr}$ pellets. NMR spectra were obtained on a Bruker DPX-250 instrument $\left(250 \mathrm{MHz}\right.$ for ${ }^{1} \mathrm{H}$ and $62.5 \mathrm{MHz}$ for ${ }^{13} \mathrm{C}$ ), in $\mathrm{CDCl}_{3}$ as the solvent. Chemical shifts are reported in $\delta$ from TMS. GC-Mass analysis was performed on a GC-Mass model: 5973 network mass selective detector, GC 6890 Agilent. Melting points were measured using the capillary tube method with an electro thermal 9200 apparatus. Transmission electron microscopy (TEM) analysis was performed on a Tecnai $\mathrm{G}^{2} \mathrm{~F} 30$ at $300 \mathrm{kV}$.

\section{2. General Procedure for the Preparation of Catalyst}

The SBA-Pr- $\mathrm{NH}_{2}$ was prepared according to our previous report. ${ }^{30}$ For the synthesis of SBA-Pr- $\mathrm{NH}_{2}$, calcined SBA-15 (5 g) was activated at $200{ }^{\circ} \mathrm{C}$ under vacuum for $5 \mathrm{~h}$ to remove any surface humidity and subsequently was refluxed in dry toluene $(150 \mathrm{~mL})$. 3-Aminopropyltrimethoxysilane (APTMS) (30.2 mmol) was then slowly added to the mixture and the reaction was refluxed at $110^{\circ} \mathrm{C}$ for $24 \mathrm{~h}$. The mixture was then filtered and washed with toluene and any residual organosilane was removed by Soxhlet extraction in ethanol over a $24 \mathrm{~h}$ period to obtain SBA-Pr- $\mathrm{NH}_{2}$.

\section{3. General Procedure for the Synthesis of Prop-2-ynyl 2-chlorobenzoate 4}

The SBA-Pr- $\mathrm{NH}_{2}(0.01 \mathrm{~g})$ was activated in vacuum at $100{ }^{\circ} \mathrm{C}$ and then after cooling to room temperature, propargyl alcohol (13 mmol, $0.75 \mathrm{~mL})$ and 2-chlorobenzoyl chloride $(10 \mathrm{mmol}, 1.3 \mathrm{~mL})$ were added to it in a $10 \mathrm{~mL}$ round bottom flask. The mixture was stirred for $15 \mathrm{~min}$ at $90{ }^{\circ} \mathrm{C}$. The completion of the reaction was indicated by TLC using $n$-hexane : ethyl acetate (3:1) as the eluent. The SBA-Pr- $\mathrm{NH}_{2}$ was separated simply by filtration and reaction mixture was dissolved in $n$-hexane. Finally, the gradual evaporation of solvent resulted in the formation of pure crystals of product 4 .

\section{4. General Procedure for the Preparation of POSS- $(\mathrm{Cl})_{8}{ }^{31}$}

3-(Chloropropyl)trimethoxysilane $(13.8 \mathrm{~mL}, 75$ mmol, $15 \mathrm{~g}$ ) was added over ten minutes to a solution mixture of concentrated $\mathrm{HCl}(5 \mathrm{~mL})$ and dry methanol $(150 \mathrm{~mL})$ at room temperature under vigorous stirring and mixed for $2 \mathrm{~h}$, followed by remaining static for $48 \mathrm{~h}$. After this time, di- $n$-butyltin dilaurate $(0.11 \mathrm{~mL}, 0.5$ mmol, $0.15 \mathrm{~g}$ ) was added as the catalyst. Finally, the white crystals of $\mathbf{2}$ were collected, washed with methanol for several times and dried under vacuum.

\section{5. General Procedure for the Preparation of POSS- $\left(\mathbf{N}^{3}\right)_{\mathbf{8}}{ }^{31}$}

POSS- $(\mathrm{Cl})_{8}(0.935 \mathrm{mmol}, 0.98 \mathrm{~g})$ and $\mathrm{NaN}_{3}(2.13 \mathrm{~g})$ were added to a flask equipped with a magnetic stirrer along with $17 \mathrm{~mL}$ of anhydrous $\mathrm{N}, \mathrm{N}$-dimethylformamide (DMF). The reaction was carried out at $120^{\circ} \mathrm{C}$ for $48 \mathrm{~h}$. After completion of the reaction, distilled water was added and the mixture was extracted with $\mathrm{CH}_{2} \mathrm{Cl}_{2}$. Organic layers were dried over anhydrous magnesium sulphate, filtered and concentrated under reduced pressure to obtain the final product; a yellow viscose liquid $\mathbf{3}$.

\section{6. General Procedure for the Preparation of POSS- $(R)_{\mathbf{8}}$ via Click Reaction}

A solution mixture of POSS- $\left(\mathrm{N}_{3}\right)_{8}(0.344 \mathrm{mmol}$, $0.375 \mathrm{~g})$, prop-2-ynyl 2-chlorobenzoate $(8.6 \mathrm{mmol}, 1.67$ $\mathrm{g})$, and $\mathrm{CH}_{2} \mathrm{Cl}_{2}(40 \mathrm{~mL})$ were added into a $100 \mathrm{~mL}$ flask. Then, $\mathrm{CuSO}_{4} 5 \mathrm{H}_{2} \mathrm{O}(0.042 \mathrm{~g})$ and sodium ascorbate $(0.66$ $\mathrm{g}$ ) were added to the solution mixture and it was kept stirring for $24 \mathrm{~h}$ at room temperature. The suspension was then filtered to remove extra unsolvable salts (copper(II) sulfate and sodium ascorbate) and was concentrated under reduced pressure. Finally, petroleum ether was added to remove all other remaining impurities and to obtain the resulted viscose liquid product 5 .

\section{7. Spectral Data of Products}

1,3,5,7,9,11,13,15-Octakis(3-chloropropyl)pentacyclo $\left[\right.$ 9.5.1.1 $\left.{ }^{3,9} \cdot 1^{5,15} \cdot 1^{7,13}\right]$ octasiloxane (2) M.p. $=208^{\circ} \mathrm{C}^{32}$. IR $(\mathrm{KBr})\left(v_{\max }, \mathrm{cm}^{-1}\right): 2955,1274$, 1108. ${ }^{1} \mathrm{H}$ NMR $\left(250 \mathrm{MHz}, \mathrm{CDCl}_{3}\right): \delta 3.52-3.57(16 \mathrm{H}, \mathrm{t}$, $\left.J=6.5 \mathrm{~Hz}, \mathrm{Si}-\mathrm{CH}_{2} \mathrm{CH}_{2} \mathrm{CH}_{2} \mathrm{Cl}\right), 1.82-1.94(16 \mathrm{H}, \mathrm{m}$, $\left.\mathrm{Si}-\mathrm{CH}_{2} \mathrm{CH}_{2}-\right), 0.77-0.84$ (16H, m, $\left.\mathrm{Si}-\mathrm{CH}_{2}-\right)$ ppm. ${ }^{13} \mathrm{C}$ NMR $\left(62.5 \mathrm{MHz}, \mathrm{CDCl}_{3}\right): \delta 9.88\left(\mathrm{Si}-\mathrm{CH}_{2}-\right) ; 26.38$ ( $\left.\mathrm{Si}-\mathrm{CH}_{2} \mathrm{CH}_{2}-\right) ; 47.06\left(\mathrm{Si}-\mathrm{CH}_{2} \mathrm{CH}_{2} \mathrm{CH}_{2} \mathrm{Cl}\right) \mathrm{ppm}$.

1,3,5,7,9,11,13,15-Octakis(3-azidopropyl)pentacyclo $\left[9.5 .1 .1^{3,9} \cdot 1^{5,15} \cdot 1^{7,13}\right]$ octasiloxane (3)

IR $(\mathrm{KBr})\left(v_{\max }, \mathrm{cm}^{-1}\right): 2940,2100,1128 .{ }^{1} \mathrm{H}$ NMR $\left(250 \mathrm{MHz}, \mathrm{CDCl}_{3}\right): \delta 3.28-3.31(16 \mathrm{H}, \mathrm{t}, J=3.25 \mathrm{~Hz}$, 
$\left.\mathrm{Si}-\mathrm{CH}_{2} \mathrm{CH}_{2} \mathrm{CH}_{2} \mathrm{~N}_{3}\right), 1.66-1.68\left(16 \mathrm{H}, \mathrm{m}, \mathrm{Si}-\mathrm{CH}_{2} \mathrm{CH}_{2}-\right)$, 0.69-0.75 (16H, m, Si-CH -$)$ ppm. ${ }^{13} \mathrm{C}$ NMR $(62.5 \mathrm{MHz}$, $\left.\mathrm{CDCl}_{3}\right): \delta 8.95\left(\mathrm{Si}-\mathrm{CH}_{2}-\right), 22.42\left(\mathrm{Si}-\mathrm{CH}_{2} \mathrm{CH}_{2}-\right), 53.36$ $\left(\mathrm{Si}-\mathrm{CH}_{2} \mathrm{CH}_{2} \mathrm{CH}_{2} \mathrm{~N}_{3}\right)$ ppm.

\section{Prop-2-ynyl 2-chlorobenzoate (4)}

M.p. $=62{ }^{\circ} \mathrm{C}$. IR $(\mathrm{KBr})\left(\mathrm{v}_{\max }, \mathrm{cm}^{-1}\right): 3256,2131$, 1720, 1258, 743. MS (m/z, \%): $194\left(\mathrm{M}^{+}\right), 159,139$ (100), $120,111,85$.

\section{1,3,5,7,9,11,13,15-Octakis(1-propyl-1H-1,2,3-triazole-} 4-yl(methyl 2-chlorobenzoate))pentacyclo[9.5.1.1 ${ }^{3,9}$ $\left..1^{5,15} \cdot 1^{7,13}\right]$ octasiloxane (5)

IR $(\mathrm{KBr})\left(v_{\max }, \mathrm{cm}^{-1}\right): 3431,2933,1730,1632$, 1592, 1439, 1116. ${ }^{1} \mathrm{H}$ NMR $\left(250 \mathrm{MHz}, \mathrm{CDCl}_{3}\right): \delta$
7.93-7.96 (2H, m), 7.45-7.46 (2H, m), 7.26-7.39 (1H, $\mathrm{m}), 5.44-5.46(2 \mathrm{H}, \mathrm{m}), 4.15-4.35(2 \mathrm{H}, \mathrm{br} \mathrm{s}), 1.65-2.10$ (2H, br s), 0.40-0.70 (2H, br s) ppm. ${ }^{13} \mathrm{C}$ NMR $(62.5$ $\left.\mathrm{MHz}, \mathrm{CDCl}_{3}\right): \delta 165.3(\mathrm{CO}), 142.4(\mathrm{C}=\mathrm{C}), 133.7(\mathrm{CCl})$, $132.9(\mathrm{CH}), 131.6(\mathrm{CH}), 131.1(\mathrm{CH}), 129.4(\mathrm{C}=\mathrm{C}), 126.7$ (CH), 124.8 (C-arom), $58.5\left(\mathrm{CH}_{2}\right), 52.4\left(\mathrm{Si}-\mathrm{CH}_{2} \mathrm{CH}_{2}\right.$ $\left.\mathrm{CH}_{2}\right), 24.0\left(\mathrm{Si}-\mathrm{CH}_{2} \mathrm{CH}_{2}-\right), 8.6\left(\mathrm{Si}-\mathrm{CH}_{2}-\right) \mathrm{ppm}$.

\section{Results and Discussion}

Here we report the synthesis of octakis(1-propyl1H-1,2,3-triazole-4-yl(methyl 2-chlorobenzoate))octasilsesquioxane 5 using $\mathrm{Cu}(\mathrm{I})$-catalyzed azide-alkyne click reaction strategy (Scheme 1).

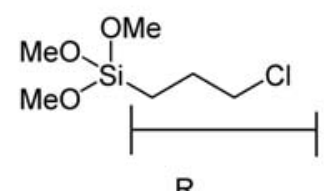

$\mathrm{R}$

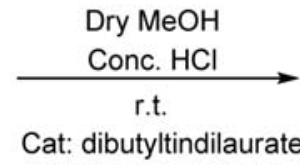

Cat: dibutyltindilaurate

\section{1}

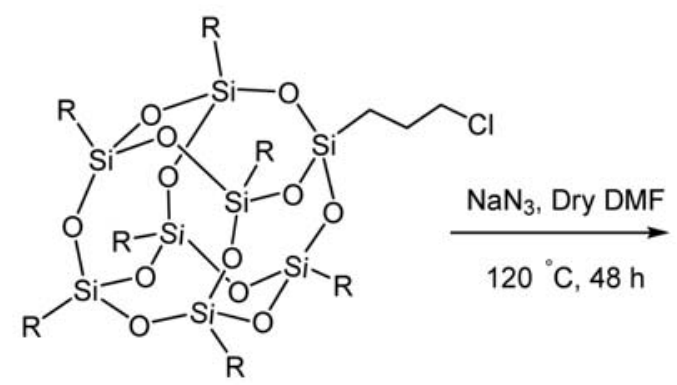

2 POSS- $(\mathrm{Cl})_{8}, 50 \%$<smiles></smiles>

$3 \mathrm{R}=\left(\mathrm{CH}_{2}\right)_{3} \mathrm{~N}_{3}, 53 \%$ click reaction

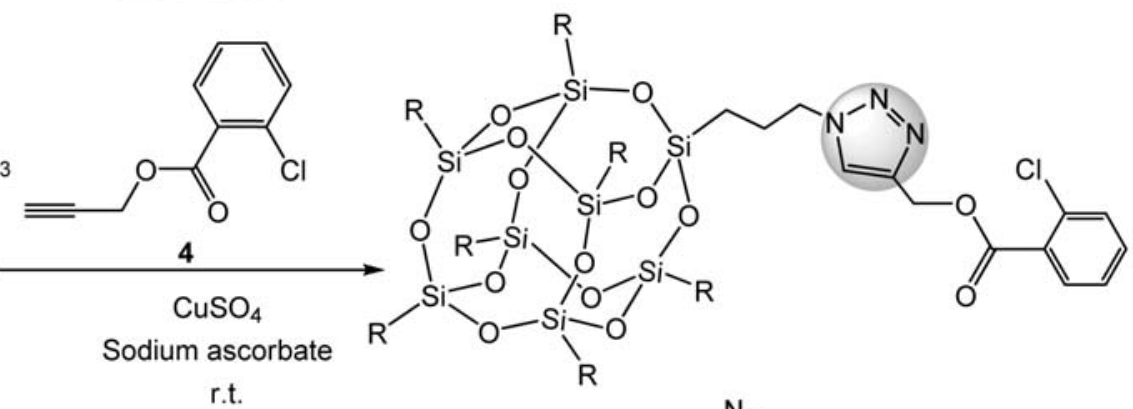

r.t.<smiles>O=C(OCc1cn([CH]C=[Hg])nn1)c1ccccc1Cl</smiles>

Scheme 1. Synthesis of octakis(1-propyl-1H-1,2,3-triazole-4-yl(methyl 2-chlorobenzoate))octasilsesquioxane 5.

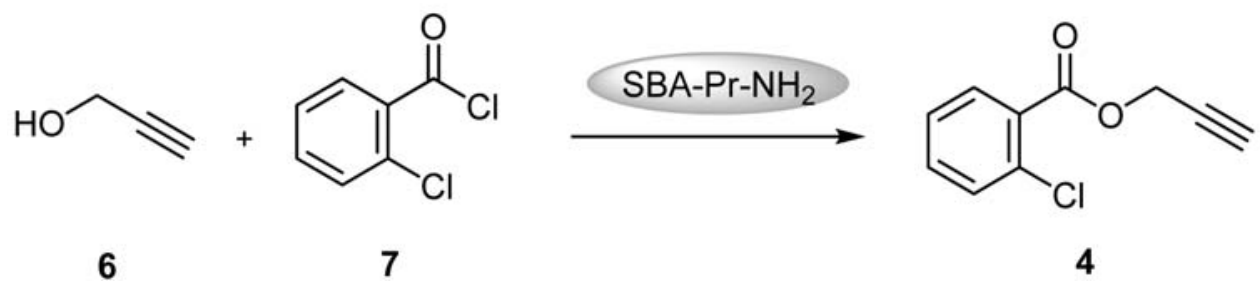

Scheme 2. Synthesis of prop-2-ynyl 2-chlorobenzoate 4 in the presence of SBA-Pr- $\mathrm{NH}_{2}$. 
In this study, prop-2-ynyl 2-chlorobenzoate 4 was selected as the propargyl-containing moiety which was synthesized via the condensation reaction of propargyl alcohol $\mathbf{6}$ and 2-chlorobenzoyl chloride 7 in the presence of SBA-Pr- $\mathrm{NH}_{2}$ as a recyclable basic catalyst (Scheme 2).

In terms of optimization of reaction conditions for the synthesis of prop-2-ynyl 2-chlorobenzoate 4, the catalyst-free system was examined and it was observed that under this condition, the reaction did not proceed satisfactory. The reaction was then carried out in the presence of SBA-Pr- $\mathrm{NH}_{2}$ under solvent-free condition at different temperatures. As shown in Table 1, among the various temperatures, the best result was obtained at $90{ }^{\circ} \mathrm{C}$. It was concluded that the yield of products is a function of temperature and the yield was increased as the reaction temperature was raised. After completion of the reaction (monitored by TLC), SBA-Pr- $\mathrm{NH}_{2}$ was separated by simple filtration and the pure crystals of product were obtained in $n$-hexane as the crystallization solvent.

Table 1 The optimization of reaction conditions for the synthesis of prop-2-ynyl 2-chlorobenzoate 4.

\begin{tabular}{|c|c|c|c|c|}
\hline Entry & Catalyst & Temp $\left({ }^{\circ} \mathrm{C}\right)$ & Time (min) & Yield (\%) \\
\hline 1 & - & r.t. & 30 & 35 \\
\hline 2 & - & r.t. & $24 \mathrm{~h}$ & 40 \\
\hline 3 & - & 60 & 20 & 58 \\
\hline 4 & SBA-Pr-NH 2 & r.t. & 15 & 68 \\
\hline 5 & SBA-Pr-NH ${ }_{2}$ & 60 & 20 & 76 \\
\hline 6 & SBA-Pr-NH 2 & 90 & 25 & 81 \\
\hline
\end{tabular}

The suggested mechanism for the SBA-Pr- $\mathrm{NH}_{2}$ catalyzed synthesis of prop-2-ynyl 2-chlorobenzoate $\mathbf{4}$ is shown in Scheme 3. First, SBA-Pr- $\mathrm{NH}_{2}$ deprotonates the $\mathrm{OH}$ group of propargyl alcohol with subsequent nucleophilic attack to carbonyl group of 2-chloro benzoyl chloride affording the final product 4.

SBA-Pr- $\mathrm{NH}_{2}$ was used as a nanoporous catalyst in the synthesis of 4 . The TEM image of SBA-Pr- $\mathrm{NH}_{2}$ (Figure 1) showed the parallel channels, which resembled the
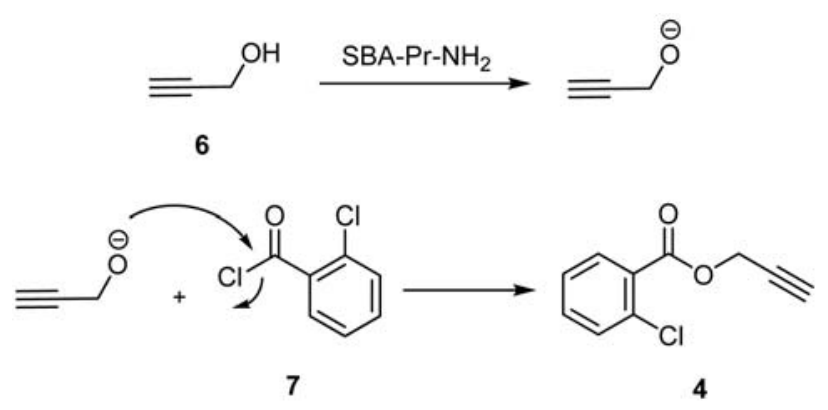

Scheme 3. Proposed mechanism. configuration of the pores in SBA-15. This indicated that the pores in SBA-Pr- $\mathrm{NH}_{2}$ had not collapsed during the functionalization reaction.

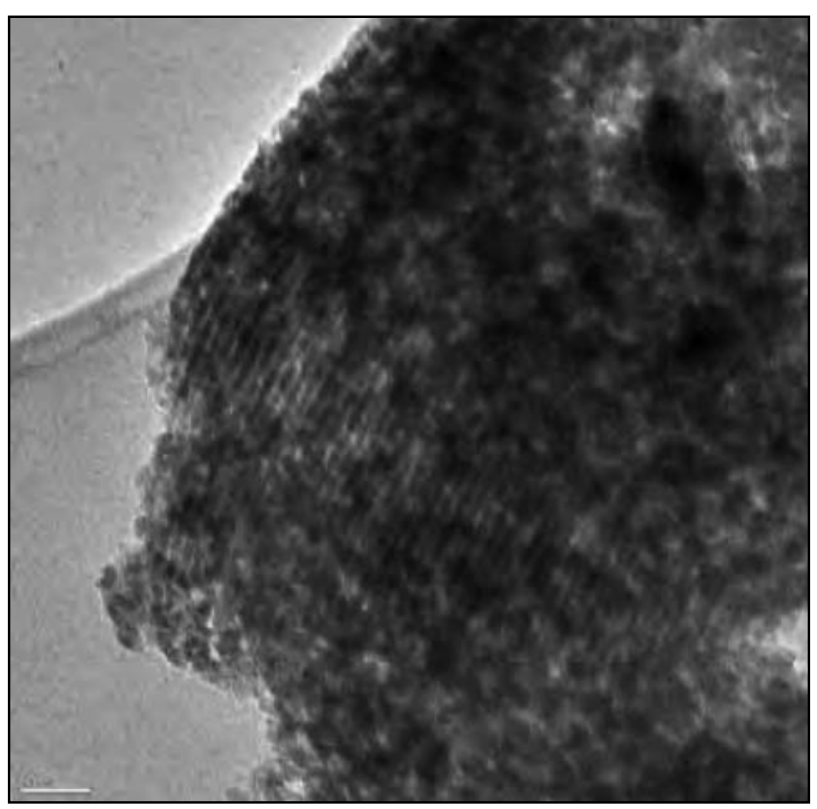

Figure 1. TEM image of $\mathrm{NH}_{2}-\mathrm{SBA}-15$.

Then, to a standard »click« protocol, first, POSS$(\mathrm{Cl})_{8} 2$ was conveniently prepared in high purity from inexpensive materials on a large scale. In this regard, the hydrolytic condensation of 3-(chloropropyl)-trimethoxysilane $\mathbf{1}$ as the precursor in dry methanol and concentrated $\mathrm{HCl}$ in the presence of di- $n$-butyltin dilaurate as the catalyst was accomplished and the desired octachloropropyl substituted POSS 2 was obtained as white crystal (Scheme 1). Analysis of X-ray diffraction (XRD) data of POSS$(\mathrm{Cl})_{8} 2$ in figure 2 exhibits the crystalline structure of this material.

In the next step, POSS-( $\left.\mathrm{N}_{3}\right)_{8} 3$ was prepared via azide exchange of POSS $-(\mathrm{Cl})_{8}$ under mild conditions via the reaction of 2 with sodium azide $\left(\mathrm{NaN}_{3}\right)$ at $120{ }^{\circ} \mathrm{C}$ in dry DMF as the solvent. After completion of the reaction, in order to remove the excess amount of $\mathrm{NaN}_{3}$, water was added to the solution mixture. Then, the crude product was extracted in $\mathrm{CH}_{2} \mathrm{Cl}_{2}$ and after evaporation of the solvent, POSS- $\left(\mathrm{N}_{3}\right)_{8} 3$ was obtained (Scheme 1).

The FT-IR spectrum of POSS- $\left(\mathrm{N}_{3}\right)_{8} 3$ revealed the presence of absorbance peak at $2100 \mathrm{~cm}^{-1}$, which is characteristic of the azide groups. This indicates that azidofunctionalized POSS has been successfully obtained (Figure $3 a, b)$.

In the final step, octakis(1-propyl-1H-1,2,3-triazole4-yl(methyl2-chlorobenzoate)) octasilsesquioxane 5 was obtained via the reaction of POSS- $\left(\mathrm{N}_{3}\right)_{8} 3$ and prop-2-ynyl 2-chlorobenzoate 4 under click reaction conditions for 24 h. $\mathrm{CuSO}_{4} 5 \mathrm{H}_{2} \mathrm{O} / \mathrm{Na}$ ascorbate system was used for the in 


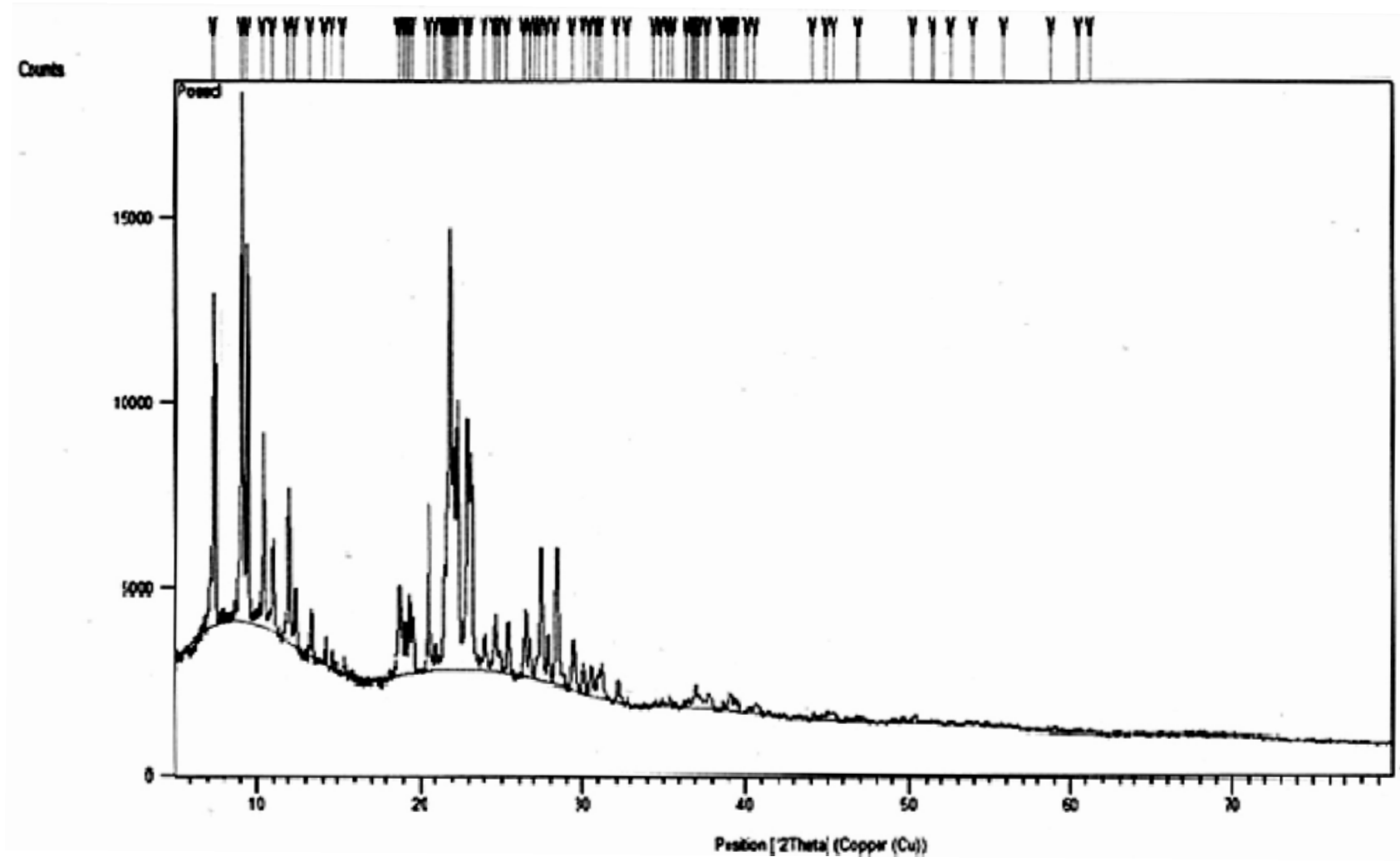

Figure 2. XRD pattern of POSS- $(\mathrm{Cl})_{8}$

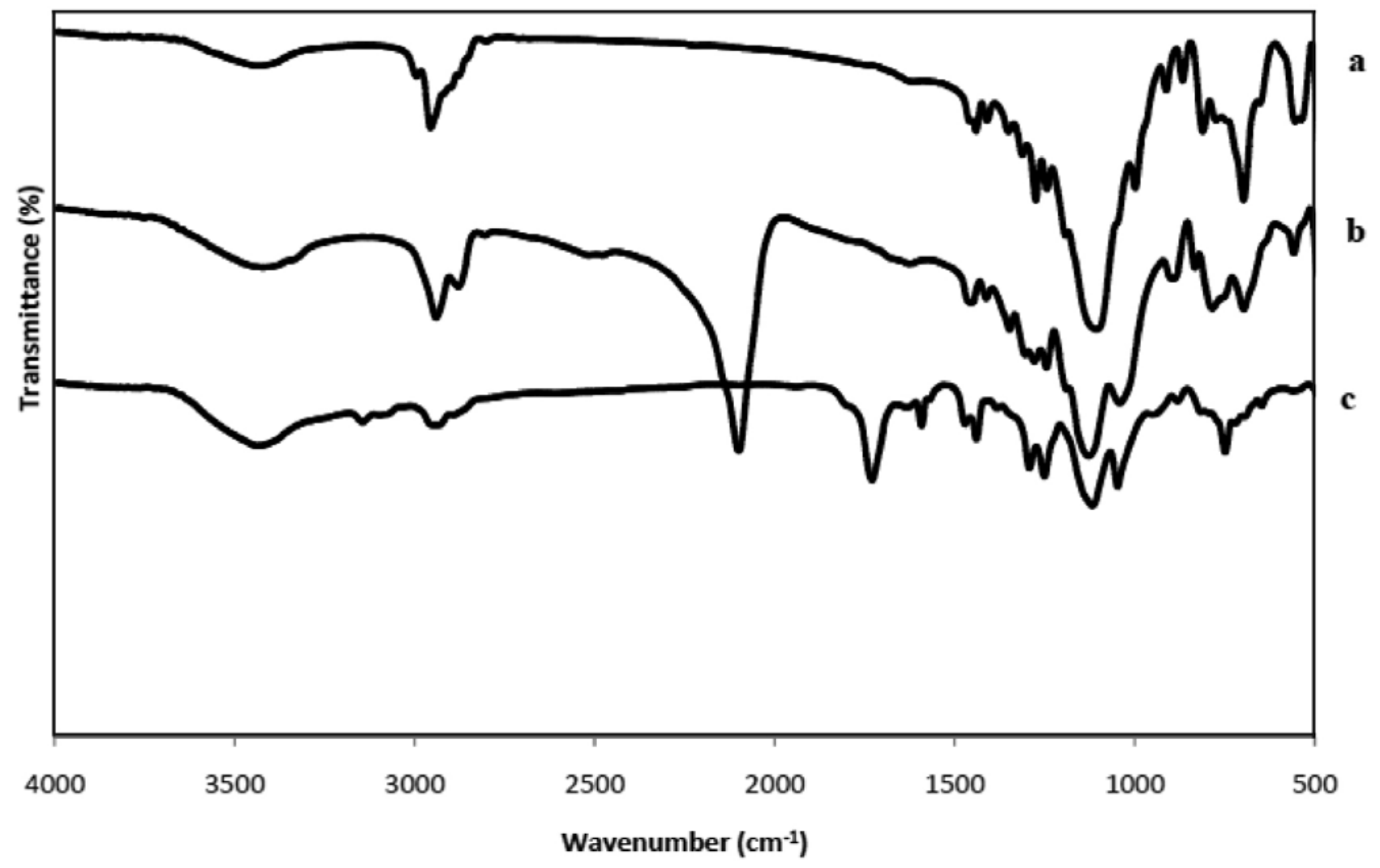

Figure 3. FT-IR spectra of (a) POSS-(Cl) $)_{8}$, (b) POSS- $\left(\mathrm{N}_{3}\right)_{8}$ and (c) click product 
situ formation of $\mathrm{CuI}$ species as the catalyst in this reaction. For this purpose, it was added to the flask containing POSS- $\left(\mathrm{N}_{3}\right)_{8}$ and $\mathrm{CH}_{2} \mathrm{Cl}_{2}$ and then, prop-2-ynyl 2-chlorobenzoate dissolved in $\mathrm{CH}_{2} \mathrm{Cl}_{2}$ was added to the reaction mixture under vigorous stirring for $24 \mathrm{~h}$ at room temperature. After completion of the reaction, excess $\mathrm{CuSO}_{4}$ and sodium ascorbate were separated by simple filtration, and the product 5 was isolated as a viscose liquid and purified by petroleum ether (Scheme 1).

Figure 3c shows IR spectrum of $\mathbf{5}$. The $\mathrm{Si}-\mathrm{O}-\mathrm{Si}$ stretching absorptions appeared at $1126 \mathrm{~cm}^{-1}$. New sharp peaks between 1900 and $1500 \mathrm{~cm}^{-1}$ were assigned to the double bond vibration of $\mathrm{C}=\mathrm{C}$ in triazole rings. Also the aliphatic $-\mathrm{CH}_{2}$ band was observed at about $2933 \mathrm{~cm}^{-1}$ and missing azide band at $2100 \mathrm{~cm}^{-1}$ was evidence of the click reaction. The $\mathrm{C}=\mathrm{O}$ stretching absorption of ester group appeared at $1730 \mathrm{~cm}^{-1}$ as a sharp peak. Finally, the stretching absorptions of ethylenic $\mathrm{C}-\mathrm{H}$ bonds were observed around $3000 \mathrm{~cm}^{-1}$.

\section{Conclusion}

In this study we have described an efficient methodology for the synthesis of octakis(1-propyl-1H-1,2,3triazole-4-yl(methyl2-chlorobenzoate))octasilsesquioxane as functionalized POSS via »click chemistry «. For this purpose, azide functionalized POSS was synthesized and reacted with prop-2-ynyl 2-chlorobenzoate under click conditions using $\mathrm{Cu}(\mathrm{I})$ as catalyst to form polyhedral oligomeric silsesquioxane. Additionally we have developed an efficient procedure for the synthesis of prop-2-ynyl 2chlorobenzoate via the reaction of 2-chlorobenzoyl chloride and propargyl alcohol in the presence of SBA-Pr$\mathrm{NH}_{2}$ as a heterogeneous solid basic catalyst. The use of SBA-Pr- $\mathrm{NH}_{2}$ in this reaction has the advantages of being reusable and environmentally benign nano-reactor enabling the reaction to take place easily in its nano-pores.

\section{Acknowledgements}

We gratefully acknowledge the financial support from the Research Council of Alzahra University and University of Tehran.

\section{References}

1. J. H. Harreld, A. Esaki, G. D. Stucky, Chem. Mater. 2003, 15, 3481-3489. http://dx.doi.org/10.1021/cm030185j

2. C. Sanchez, B. Lebeau, F. Chaput, J. P. Boilot, Adv. Mater. 2003, 15, 1969-1994.

http://dx.doi.org/10.1002/adma.200300389

3. D. B. Cordes, P. D. Lickiss, F. Rataboul, Chem. Rev. 2010, 110, 2081-2173. http://dx.doi.org/10.1021/cr900201r
4. P. D. Lickiss, F. Rataboul, Adv. Organomet. Chem. 2008, 57, 1-116. http://dx.doi.org/10.1016/S0065-3055(08)00001-4

5. C. Ni, G. Wu, C. Zhu, B. Yao, J. Phys. Chem. C 2010, 114, 13471-13476. http://dx.doi.org/10.1021/jp103260h

6. K. Tanaka, Y. Chujo, J. Mater. Chem. 2012, 22, 1733-1746. http://dx.doi.org/10.1039/C1JM14231C

7. O. Smrtka, J. Jančár, Chem. Pap. 2008, 62, 504-508. http://dx.doi.org/10.2478/s11696-008-0054-7

8. J. Choi, R. Tamaki, S. G. Kim, R. M. Laine, Chem. Mater. 2003, 15, 3365-3375. http://dx.doi.org/10.1021/cm030286h

9. H. Liu, S. Zheng, K. Nie, Macromolecules 2005, 38, 50885097. http://dx.doi.org/10.1021/ma0504318

10. J.-C. Huang, C.-B. He, Y. Xiao, K. Y. Mya, J. Dai, Y. P. Siow, Polymer 2003, 44, 4491-4499.

http://dx.doi.org/10.1016/S0032-3861(03)00434-8

11. T. K. Minton, M. E. Wright, S. J. Tomczak, S. A. Marquez, L. Shen, A. L. Brunsvold, R. Cooper, J. Zhang, V. Vij, A. J. Guenthner, B. J. Petteys, ACS Appl. Mater. Interfaces 2011, 4, 492-502. http://dx.doi.org/10.1021/am201509n

12. H. Wang, H. Zhou, A. Gestos, J. Fang, H. Niu, J. Ding, T. Lin, Soft Matter 2013, 9, 277-282. http://dx.doi.org/10.1039/C2SM26871J

13. Y.-H. La, R. Sooriyakumaran, B. D. McCloskey, R. D. Allen, B. D. Freeman, R. Al-Rasheed, J. Membr. Sci. 2012, 401402, 306-312. http://dx.doi.org/10.1016/j.memsci.2012.02.021

14. G. Li, L. Wang, H. Ni, C. Pittman, Jr., J. Inorg. Organomet. Polym. 2001, 11, 123-154. http://dx.doi.org/10.1023/A:1015287910502

15. V. Ervithayasuporn, T. Tomeechai, N. Takeda, M. Unno, A. Chaiyanurakkul, R. Hamkool, T. Osotchan, Organometallics 2011, 30, 4475-4478. http://dx.doi.org/10.1021/om200477a

16. K. Pielichowski, J. Njuguna, B. Janowski, J. Pielichowski, in Supramolecular Polymers Polymeric Betains Oligomers, Springer Berlin Heidelberg, 2006, pp. 225-296. http://dx.doi.org/10.1007/12_077

17. H.-C. Lin, S.-W. Kuo, C.-F. Huang, F.-C. Chang, Macromol. Rapid Commun. 2006, 27, 537-541. http://dx.doi.org/10.1002/marc.200500852

18. D. Neumann, M. Fisher, L. Tran, J. G. Matisons, J. Am. Chem. Soc. 2002, 124, 13998-13999. http://dx.doi.org/10.1021/ja0275921

19. P. Maitra, S. L. Wunder, Chem. Mater. 2002, 14, 4494-4497. http://dx.doi.org/10.1021/cm0203518

20. G. H. Mehl, J. W. Goodby, Angew. Chem. Int. Ed. 1996, 35, 2641-2643. http://dx.doi.org/10.1002/anie.199626411

21. H. C. Kolb, M. G. Finn, K. B. Sharpless, Angew. Chem. Int. Ed. 2001, 40, 2004-2021.

http://dx.doi.org/10.1002/1521-3773(20010601)40:11 $<2004:$ :AID-ANIE2004>3.0.CO;2-5

22. V. V. Rostovtsev, L. G. Green, V. V. Fokin, K. B. Sharpless, Angew. Chem. Int. Ed. 2002, 41, 2596-2599. http://dx.doi.org/10.1002/1521-3773(20020715)41:14 $<2596:$ :AID-ANIE2596>3.0.CO;2-4

23. S. Fabritz, D. Heyl, V. Bagutski, M. Empting, E. Rikowski, H. Frauendorf, I. Balog, W.-D. Fessner, J. J. Schneider, O. Avru- 
tina, H. Kolmar, Org. Biomol. Chem. 2010, 8, 2212- 2218. http://dx.doi.org/10.1039/b923393h

24. V. Ervithayasuporn, X. Wang, Y. Kawakami, Chem. Commun. 2009, 5130-5132. http://dx.doi.org/10.1039/b909802j

25. M. Ak, B. Gacal, B. Kiskan, Y. Yagci, L. Toppare, Polymer 2008, 49, 2202-2210. http://dx.doi.org/10.1016/j.polymer.2008.03.023

26. Z. Ge, D. Wang, Y. Zhou, H. Liu, S. Liu, Macromolecules 2009, 42, 2903-2910. http://dx.doi.org/10.1021/ma802585k

27. G. Mohammadi Ziarani, N. Lashgari, A. Badiei, Sci. Iran. 2013, 20, 580-586.

28. G. Mohammadi Ziarani, A. Badiei, M. Azizi, N. Lashgari, J. Chin. Chem. Soc. 2013, 60, 499-502.

http://dx.doi.org/10.1002/jccs.201200530
29. P. Gholamzadeh, G. Mohammadi Ziarani, A. Badiei, A. Abolhassani Soorki, N. Lashgari, Res. Chem. Intermed. 2013, 39, 3925-3936. http://dx.doi.org/10.1007/s11164-012-0909-y

30. G. Mohammadi Ziarani, A. Badiei, S. Mousavi, N. Lashgari, A. Shahbazi, Chin. J. Catal. 2012, 33, 1832-1839. http://dx.doi.org/10.1016/S1872-2067(11)60456-7

31. W. Yuan, X. Liu, H. Zou, J. Ren, Polymer 2013, 54, 53745381. http://dx.doi.org/10.1016/j.polymer.2013.08.008

32. M. Lei, Y. G. Wang, F. F. Zhang, C. Huang, X. Xu, R. Zhang, D. Y. Fan, Electrochim. Acta 2014, 149, 206-211. http://dx.doi.org/10.1016/j.electacta.2014.10.041

\section{Povzetek}

S pomočj klik reakcije (z bakrom katalizirane Huisgenove 1,3-dipolarne cikloadicijske reakcije) med azido funkcionaliziranim silseskvioksanom in prop-2-inil-2-klorobenzoatom smo sintetizirali oktakis(1-propil-1H-1,2,3-triazol-4il(metil-2-klorobenzoat))oktasilseskvioksane kot primere funkcionaliziranih silseskvioksanov. Te smo pripravili s kondenzacijsko reakcijo propargil alkohola in 2-klorobenzoil klorida v prisotnosti SBA-Pr- $\mathrm{NH}_{2}$ (amorfni Santa Barbara tip materiala) kot bazičnega nano katalizatorja. Tovrstni pristop omogoča enostavno in prikladno pot za učinkovito funkcionalizacijo širokega nabora novih struktur na površini silseskvioksanov. 